\title{
TINGGI BADAN DAN PERILAKU MEROKOK ORANGTUA BERPOTENSI TERJADINYA STUNTING PADA BALITA
}

\author{
Humairoh Abdul Kadir Zubaidi \\ Fakultas Kedoktern, Universitas Lampung, Jl. Prof. DR. Ir. Sumatri Brojonegoro No.1, Gedong Meneng, \\ Kec. Rajabasa, Kota Bandar Lampung, Lampung, Indonesia 35145 \\ humairohzubaidi53@gmail.com (+6282281044358)
}

\begin{abstract}
ABSTRAK
Stunting menjadi masalah gizi di dunia karena menimbulkan peningkatan morbiditas dan mortalitas, penurunan perkembangan kognitif, motorik, dan bahasa, kemampuan belajar, kapasitas kerja. Sehingga penting untuk mengetahui faktor risiko untuk mencegah terjadinya stunting. Tinggi badan ibu merupakan faktor penting yang menjadi penanda status gizi ibu sementara asap rokok mengandung bahan aktif yang mempengaruhi distribusi nutrisi dan oksigen. Review literature dilakukan dengan mencari dengan kata kunci stunting, cigarette smoke, dan short mother pada Google Scholar, PubMed dan Elsevier. Pencarian literature mendapatkan 18 artikel yang kemudian direview. Hasil review sebuah penelitian menunjukkan perilaku merokok ibu mempengaruhi timbulnya severe stunting (OR 1,45;95\% CI =1,29-1,71). Perilaku ayah merokok di dalam rumah berhubungan signifikan dengan kejadian stunting $(\mathrm{p}<0,05)$. Penelitian lain mendapatkan hasil balita yang mengalami stunting memiliki orang tua dengan perilaku merokok tidak efektif lebih banyak dibandingkan orang tua dengan perilaku merokok efektif. Penelitian lain menunjukkan ibu dengan tinggi badan pendek 30,4\% memiliki anak pendek dan 34,8\% memiliki anak sangat pendek dengan uji korelasi Rank Spearman didapatkan hasil $\mathrm{p}$ value $0,000(\mathrm{p}<0,05)$. Hal ini menunjukkan terdapat hubungan tinggi badan ibu dan perilaku merokok orangtua terhadap kejadian stunting pada balita. Perilaku merokok orang tua berpengaruh terhadap kejadian stunting hal ini berkaitan dengan efek asap rokok yang menyebabkan terhambatnya penyerapan gizi pada anak sementara tinggi badan ibu berpengaruh terhadap kejadian stunting terkait dengan risiko terjadinya (IUGR) yang menjadi salah satu faktor terjadinya stunting
\end{abstract}

Kata kunci: kebiasaan merokok; stunting; tinggi badan ibu

\section{RELATION BETWEEN MATERNAL HEIGHT AND PARENTAL SMOKING BEHAVIOR TOWARDS STUNTING IN CHILDREN}

\begin{abstract}
Stunting is world nutrition problem since it can cause increase morbidity and mortality, decrease of cognitive, motoric, and language development, learning ability and work capacity. Mother's height is an important factor as mother's nutritional status marker while cigarette smoke contains active substances which affect nutrition and oxygen distribution. Literature review is done by searching keywords stunting, cigarette smoke, and short mother in Google Scholar, Pubmed, and Elsevier. Literature searching found 18 related article that later being reviewed. Literature review result in an experiment shows that mother's smoking behavior affecting the emerging of severe stunting (OR 1,45;95\% CI =1,29-1,71). Father's smoking behavior inside the house has significant connection with the emerging of stunting $(p<0,05)$. Other experiment shows that the amount of children with stunting have parents with noneffective smoking behavior are higher than parents with effective smoking behavior. Other experiment shows that mother with short height 30,4\% have short children and 34,8\% have very short children with Rank Spearman correlation test result p value 0,000 (<0,05). These shows
\end{abstract}


that there is relation between maternal height and parental smoking behavior toward stunting in children Parents smoking behavior has effect on the emerging stunting that's relate to the effect of cigarette smoke that cause delay in nutrient absorption in child while mother's height effecting the emerging stunting by the risk of IUGR which is one of stunting causing factor.

Keywords: smoking behavior; stunting; maternal height

\section{PENDAHULUAN}

Balita pendek (stunting) adalah kegagalan balita dalam mencapai pertumbuhan optimal sehingga pertumbuhan tidak sempurna yang dapat dinilai dari perbandingan tinggi badan dengan usia balita berdasarkan Zscore $\leq-2 \mathrm{SD}$ yang disebabkan oleh kekurangan gizi kronis sejak dalam kandungan dan masa awal setelah bayi lahir akan tetapi kondisi stunting baru akan tampak setelah anak berusia 2 tahun (Ratu, 2018). Kejadian balita pendek merupakan masalah gizi di dunia dengan angka kejadian pada tahun 2017 mencapai 22,2\% atau sekitar 150,8 juta balita di dunia dengan $55 \%$ atau 83,6 juta balita berasal dari Asia. Indonesia menempati urutan ke 9 di Asia Tenggara dengan rata-rata prevalensi 36,4\% (Pusdatin, 2018). Prevalensi balita pendek di Indonesia tahun 2019 adalah 27,67\% menempati urutan paling tinggi dibandingkan dengan masalah gizi balita lainnya seperti gizi kurang, kurus dan gemuk dengan prevalensi di provinsi Lampung $26,3 \%$ dengan beberapa kabupaten masuk ke dalam prioritas penurunan stunting (Balitbangkes, 2020).

Kejadian balita pendek (stunting) menimbulkan peningkatan morbiditas dan mortalitas, penurunan perkembangan kognitif, motorik, dan bahasa, peningkatan pengeluaran biaya kesehatan, risiko obesitas dan komorbid yang timbul akibat obesitas, selain itu stunting menyebabkan penurunan kesehatan reproduksi, kecerdasan, kapasitas belajar, kemampuan dan kapasitas kerja (Hanum, 2019). Menurut
WHO (2013) terdapat beberapa faktor yang dapat menimbulkan stunting: rumah tangga dan keluarga, kurangnya makanan tambahan atau komplementer, pemberian ASI, faktor infeksi.

Tinggi badan ibu yang rendah dan intrauterine growth retardation (IUGR) hal ini akan menyebabkan terjadinya BBLR. Ibu dengan tinggi badan rendah mengakibatkan terjadinya gangguan aliran darah pada rahim sehingga kekurangan sirkulasi dan nutrisi akan menimbulkan gangguan pada uterus, plasenta, dan janin menyebabkan BBLR (Hanum, 2019). Masalah stunting merupakan masalah terintegrasi sehingg orang tua yang stunting akan melahirkan anak dengan BBLR. Berdasarkan penelitian yang pernah dilakukan didapatkan bahwa tinggi badan ibu merupakan faktor penting yang menghambat pertumbuhan intrauterine (IUGR), BBLR, dan balita pendek (stunting). Penelitian lain menunjukkan ibu dengan tinggi badan kurang dari $150 \mathrm{~cm}$ akan lebih berisiko untuk melahrikan anak stunting (Husna, 2017).

Hasil studi yang pernah dilakukan menunjukkan bahwa faktor keturunan hanya berperan $15 \%$ dan faktor terbesar adalah asupan gizi, hormon pertumbuhan dan terjadinya penyakit infeksi berulang. Faktor lingkungan ikut berperan dalam terjadinya balita pendek, balita yang tinggal dengan paparan polusi dari asap rokok yang mengandung karbon monoksida dan benzene serta berbagai bahan aktif yang bersifat toksik menyebabkan penurunan 
jumlah sel darah merah dan merusak sel sumsum tulang sehingga rentan mengalami anemia. Sel darah merah berperan dalam mengangkut oksigen dan zat nutrient untuk didistribusikan ke seluruh tubuh, penurunan jumlah sel darah merah akan menyebabkan penurunan jumlah oksigen dan nutrisi yang didistribusikan dalam tubuh terutama pada jaringan kelenjar yang menghasilkan hormone pertumbuhan berkurang (Sari, 2020). Berdasarkan hal ini maka penulis merasa perlu untuk melakukan kajian terkait hubungan tinggi badan ibu dan perilaku merokok orang tua terhadap kejadian stunting pada balita dengan tujuan untuk mengetahui hubungan tinggi badan ibu dan kebiasaan merokok orang tua dengan kejadian stunting pada balita.

\section{METODE}

Metode yang digunakan dalam penulisan ini adalah studi literature dari berbagai jurnal internasional maupun nasional yang terkait. Sebelum melakukan review literatur, penulis membuat pertanyaan penelitian sebagai pedoman dalam mencari literaur yang relevan. Pertanyaan penelitian yang digunakan adalah apakah tinggi badan ibu dan kebiasaan merokok orang tua berpengaruh pada kejadian stunting pada balita?

Setelah mendapatkan pertanyaan penelitian, dilakukan pencarian literature yang relevan di database elektronik dengan filter data tahun 2017-sekarang menggunakan Google Scholar, PubMed, PMC, dan Elsevier. Kata kunci yang digunakan dalam pencarian adalah [cigarette smoke], [short mother], dan [stunting], didapatkan 18 literature relevan yang kemudian direview untuk mendapatkan hubungan antara tinggi badan ibu dan kebiasaan merokok orang tua dengan kejadian stunting pada balita.

\section{HASIL}

Penelitian Wardani (2020) mengenai akses sanitasi, merokok dan annuall parasite incidence malaria sebagai faktor risiko stunting baduta di Indonesia menggunakan analisis regresi menunjukkan hasil regresi tahap pertama bahwa kebiasaan merokok penduduk usia $\geq 15$ tahun memiliki nilai $\mathrm{p}<\alpha(0,091)$ dimana hal ini menunjukkan bahwa terdapat pengaruh signifikan kebiasaan merokok penduduk usia $\geq 15$ tahun terhadap prevalensi stunting bayi di bawah dua tahun (baduta) di Indonesia pada tahun 2018. Pada regresi kedua didapatkan bahwa apabila penduduk usia $\geq 15$ tahun yang merokok diturunkan satu satuan hal ini akan menyebabkan prevalensi stunting baduta berkurang sebesar 0,571. Penelitian ini menunjukkan bahwa perilaku merokok ibu berhubungan dengan timbulnya severe stunting (OR $1,45 ; 95 \% \mathrm{CI}=1,29-1,71)$. Perilaku ayah merokok di dalam rumah berhubungan signifikan dengan kejadian stunting $(\mathrm{p}<0,05)$. Hal ini terjadi karena rokok memberi efek imunosupresan sehingga anak lebih rentan selain itu penelitian sebelumnya menunjukkan bahwa paparan asap rokok lebih dari 3 jam sehari menyebabkan peningkatan risiko stunting pada balita hingga 10,316 kali.

Penelitian Sari (2020) di wilayah kerja Puskesmas Kintamani I dengan jumlah sampel 57 orang dengan instumen kuesioner perilaku merokok dan kuesioner stunting didapatkan hasil distribusi sikap merokok baik 33 responden $(57,9 \%)$ dan sikap merokok kurang baik berjumlah 24 responden $(42,1 \%)$. Distribusi kejadian stunting didapatkan 30 responden $(52,6 \%)$ 
mengalami stunting dan 27 responden $(47,4 \%)$ tidak stunting. Analisis hubungan perilaku merokok dengan kejadian stunting didapatkan hasil balita yang mengalami stunting memiliki orang tua dengan perilaku merokok efektif sebanyak 10 responden $(17,5 \%)$ dan yang tidak stunting dengan otang tua dengan perilaku merokok yang efektif sebanyak 18 responden $(31,6 \%)$. Sedangkan perilaku merokok yang tidak efektif dan memiliki balita stunting yaitu sebanyak 20 responden $(35,1 \%)$ dan yang tidak stunting sebanyak 9 responden $(5,8 \%)$.

Pada penelitin Ramadhan (2020) dengan 46 responden ibu dan anak menunjukkan bahwa ibu dengan tinggi badan normal cenderung memiliki anak yang tidak stunting yaitu $82,6 \%$ sementara ibu dengan tinggi badan pendek $30,4 \%$ memiliki anak pendek dan $34,8 \%$ memiliki anak sangat pendek dengan uji korelasi rank spearman didapatkan hasil $\mathrm{p}$ value $0,000 \quad(p<0,05)$ hal ini menunjukkan adanya hubungan antara tinggi badan ibu dengan kejadian stunting pada anak usia 3-5 tahun di puskesmas kopelma darusalam dengan nilai $r=0,529$ yang menunjukkan hubungan yang kuat.

\section{PEMBAHASAN}

Istilah stunting diciptakan oleh Waterlow sebagai ukuran untuk mengklasifikasikan keparahan kekurangan nutrisi protein dan energi serta pertumbuhan yang tidak adekuat pada studi komunitas dengan menggunakan Z-skor tinggi per usia untuk menilai malnutrisi menyatakan bahwa stunting adalah kegagalan tumbuh akibat malnutrisi sehingga stunting merupakan indikator malnutrisi (Perumal, 2018).
Stunting merupkan kondisi dimana didapatkan hasil Z-skor tinggi per usia (HAZ) sesuai gender < -2SD. HAZ dihitung berdasarkan nilai median tinggi per usia sesuai gender pada populasi standard yang dibagi dengan SD dari populasi standar. Anak dengan tinggi yang tidak sesuai dengan usia namun memiliki Z-skor >-2SD termasuk ke dalam growth faltering bukan stunting (Leroy, 2019).

Stunting menyebabkan masalah perkembangan pada anak terutama pada baduta, sehingga terjadi hambatan perkembangan kognitif dan motorik yang akan mempengaruhi kemampuan anak menerima pelajaran dan efek jangka panjang akan mempengaruhi produktivitas kerja saat dewasa. Anak yang mengalami stunting memiliki risiko penyakit jantung, diabetes, dan obesitas, selain itu efek stunting secara ekonomi akan menambah beban Negara karena populasi dengan produktivitas kerja rendah meningkat (Suryanegara, 2020).

Penelitian yang dilakukan Hasanah (2020) mengidentifikasi beberapa faktor risiko yang menyebabkan stunting pada anak yaitu water, sanitation, and hygiene (WASH) yang buruk, BBLR, riwayat diare, imunisasi yang tidak lengkap dan adanya anggota keluarga yang merokok. Penelitian lain oleh Siswati (2019) menyatakan bahwa kehamilan di usia tua, BBLR, tinggi badan ibu rendah, ekonomi menengah ke bawah, dan water, sanitation, and hygiene (WASH) yang buruk merupakan faktor risiko stunting pada balita.

Tinggi badan ibu rendah adalah tinggi ibu yang kurang dari $145 \mathrm{~cm}$ dimana postur tubuh ibu yang pendek dan berat badan ibu yang rendah menunjukkan 
status nutrisi ibu yang buruk, hal ini memiliki hubungan dengan kejadian stunting pada balita. Kekurangan nutrisi dan pertumbuhan linier yang buruk akan menimbulkan efek jangka panjang yang saling berkaitan. Anak yang dilahirkan oleh ibu dengan berat badan dan tinggi badan rendah cenderung mengalami hambatan pertumbuhan intrauterine (IUGR) dan small for gestational age (SGA). Kondisi ini berpotensi untuk berlanjut dan menyebabkan gangguan pertumbuhan dan stunting pada usia balita (Dorsey, 2017). Hal ini juga sejalan dengan penelitian oleh Siswati (2019) mengenai faktor risiko stunting dan severe stunting pada balita di daerah pedesaan di Indonesia yang menunjukkan tinggi badan ibu berperan dalam kejadian stunting pada balita.

Asap rokok mengandung 2256 bahan kimia berbahaya yang bersifat prooksidan maupun karsinogen, banyak dari bahan kimia ini dapat menembus sawar gas darah dan masuk ke peredaran darah dan jaringan perifer, efek zat yang terkandung dalam rokok salah satunya adalah ngguan vasodilatasi yang mempengaruhi distribusi oksigen dalam tubuh, selain itu kandungan asap rokok akan merangsang sekresi sitokin proinflamasi (Nogueira, 2018).

Asap rokok yang dapat mempengaruhi pembuluh darah dan distribusinya ke jaringan menyebabkan efek langsung pada pertumbuhan anak yang terpapar asap rookok dengan menyebabkan gangguan absorbsi nutrisi pada anak yang mengganggu pertumbuhan dan perkembangan anak. Fungsi abnormal leukosit juga ditemukan pada anak dengan orang tua perokok, selain itu nikotin yang terkandung dalam asap rokok akan bereaksi langsung dengan chondrosit melalui reseptor special nikotin yang menyebabkan terhambatnya pertumbuhan tulang pada anak (Hasanah, 2020).

Penelitian yang dilakukan oleh Prince (2021) menunjukkan bahwa paparan asap rokok berhubungan dengan BBLR dan bayi lahir pendek dimana BBLR merupakan faktor risiko terjadinya stunting hal ini berkaitan dengan menurunnya aliran darah di plasenta akibat gangguan distribusi oksigen dan nutrisi oleh peningkatan sitokin dan karbon monoksida dan nikotin yang terhirup. Kekurangan nutrisi juga dapat terjadi pada balita akibat pendapatan keluarga yang lebih banyak dihabiskan untuk membeli rokok dibangdingkan untuk memenuhi kebutuhan nutrisi keluarga terutama balita (Nadhiroh, 2020).

\section{SIMPULAN}

Tinggi badan ibu dan perilaku merokok orang tua berpengaruh terhadap kejadian stunting pada anak hal ini berkaitan dengan terhambatnya penyerapan gizi pada anak dan prioritas biaya belanja rokok dibandingakan dengan biaya belanja makanan bergizi yang dibutuhkan untuk tumbuh kembang anak, risiko terjadinya gagal tumbuh intrauterus (IUGR) yang menjadi salah satu faktor terjadinya stunting.

\section{DAFTAR PUSTAKA}

Balitbangkes [Badan Penelitian dan Pengembangan Kesehatan]. 2020. Studi status gizi balita terintegrasi susenas 2019. Jakarta. Balitbangkes.

Dorsey JL, Manohar S, Neupane S, Shrestha B, Klemm RDW,West Jr. KP. 2017. Individual, household, and community level 
risk factors of stunting in children younger than 5 years, finding form a national surveillance system in Nepal. MCN. (14):1-16

Hanum NH. 2019. Hubungan tinggi badan ibu dan riwayat pemberian MP-ASI dengan kejadian stunting pada balita usia 24-59 bulan. AMNT. 3 (2):78-84

Hasanah U, Maria IL, Jafar N, Hardianti A, Mallongi A, Syam A. 2020. Water, sanitation dan hygiene analysis, and individual factors for stunting among children under two years in Ambon. MJMS. (30):8:22-6

Husna M. 2017. Hubungan tinggi badan ibu dengan kejadian stunting pada anak usia 24-59 bulan di wilayah puskesmas Minggir, kabupaten Sleman, Yogyakarta, Tahun 2016. [Skripsi]. Yogyakarta. Politeknik Kesehatan Kementrian Kesehatan.

Leroy JL, Frongillo EA. 2019. Prespective, what does stunting really mean? a critical review of the evidence. ASN:11:196-204

Nadhiroh SR, Djokosujono K, Utari DM. 2020. Socioeconomic characteristics, paternal smoking and secondhand tobacco smoke exposure among infants in Jakarta, Indonesia.TID: (38):18:19

Nogueira L, Trisko BM, Lima-Rosa FL, Jackson J. 2018. Cigarette smoke directly impairs skeletal muscle function through capillary regression and altered myofibre calcium kinetics in mice. JP.(596):14:2901-16

Perumal N, Bassani DG, Roth DE. 2018. Use and misuse of stunting as a measure of child health.ASN.148: 311-5

Prince PM, Umman M, Fathima FN, Johnson AR. 2021. Secondhand smoke exposure during pregnancy and its effect on birth outcomes, evidence from a retrospective cohort study in a tertiary care hospital in Bengaluru. IJCM:(46):1:102-6

Pusdatin [Pusat Data dan Informasi]. 2018. Situasi balita pendek (stunting) di Indonesia. Jakarta. Pusdatin

Ramadhan MH, Salawati L, Yusuf S. 2020. Hubungan tinggi badan ibu, sosial ekonomi dan asupan sumber zinc dengan kejadian stunting pada anak usia 3-5 tahun di puskesmas kopelma Darussalam. Averrous. 6 (1):5565

Ratu NC, Punuh MI, Malonda SH. 2018. Hubungan tinggi badan orangtua dengan kejadian stunting pada anak usia 24-59 bulan di kecamatan Ratahan kabupaten Minahasa Tenggara. KESMAS. 7(4):2

Sari NAME, Resiyanthi NKA. 2020. Kejadian stunting berkaitan dengan perilaku merokok orang tua. JIKA. 3 (2):24-30

Siswati T. 2019. Risk factors for stunting and severe stunting among under five years children in rural area in Indonesia. IJSR. (8):11:1635-40

Suryanegara W, Reviani N. 2020. The relationship between risk factors and stunting incidence in Desa Cilembu Kecamatan Pamulihan Kabupaten Sumedang Provinsi 
Jawa Barat on September 2019. SST. (63):5:5341-56

Wardani Z, Sukandar D, Baliwati YF, Riyadi H. 2020. Akses sanitasi, merokok dan annual parasite incidence malaria sebagai prediktor stunting baduta di Indonesia. 16 (1):127-39 
Jurnal Penelitian Perawat Profesional, Volume 3 No 2 Hal 279 - 286, Mei 2021 Global Health Science Group 